\title{
Empirical Research on the Contribution of Human Capital to the Development of Tertiary Industry in Shandong Province
}

\author{
Jie Fang \\ College of Business Administration \\ Qilu University of Technology \\ Ji'nan City, China \\ 13964013182@163.com
}

\begin{abstract}
In the context of transformation of economic development patterns and readjusting industrial structure, human capital gradually replacing material capital, land and other factors of production, has become an important engine of economic and social development, and has also become a hot topic in the research of domestic and foreign experts and scholars Human capital has become the precondition of absorption and diffusion of knowledge and technology, and can significantly promote the improvement of TFP. In this paper, based on the Romer's knowledge spillover model, taking Shandong Province as an example, the paper selected the relevant data of 1997-2012 for linear regression to verify the degree of contribution which human capital promotes to the development of the third industry in Shandong province. The conclusion: the stock and level of human capital will have a positive contribution to the development of the tertiary industry. And this paper will accordingly put forward some related policy recommendations to promote the development of tertiary industry. (Abstract)
\end{abstract}

Keywords-Human capital; Romer's knowledge spillover model; The tertiary industry; Contribution degree

\section{INTRODUCTION}

Since the reform and opening up, the development of three industries in Shandong province has made great progress and the performances are economic operation stability, the readjustment of the industrial structure advancing steadily and significant enhancement of comprehensive competitiveness. According to preliminary calculation, the province's GDP reached 5. 45trillion yuan in 2013, and increased by $9.6 \%$ compared to the previous year. Among them, the tertiary industry added value was 2. 25 trillion yuan, and increased by 9 . $2 \%$ compared to the previous year. The proportion of three industries was from last year's 8. 6: 51. 4: 40.0 adjusted to 8. 7: 50. 1:41. 2. $<$ the outline of the 12th five-year development plan in Shandong Province> pointed out that striving to 2015 the province's service industry added value accounts for the proportion of GDP increased to more than $45 \%$, the proportion of employees more than $40 \%$, and the proportion of three industries adjusted to 7:48:45.

In the process of the development of the third industry, and in the context of transformation of economic development patterns and readjusting industrial structure, the focus of the comprehensive competition of a region is the number of human capital stock. The human capital theory born in 1950s, the

\author{
Yufang Chao* \\ College of Business Administration of Qilu University of \\ Technology \\ Ji'nan City, China \\ chaochuwen@sina.com \\ *Corresponding author
}

theory held that human capital as a special capital resources was the most important of all resources; In economic growth, the role of human capital is greater than the role of physical capital, which is a powerful driving force for economic development. Especially since the mid-1980s, the new economic growth theory which was represented by Romer, Lucas and so on was born, including the human capital in economic growth model, and thought that the human capital determined the rate of economic growth, and was to promote economic development "engine". In view of the relationship between human capital effect on economic growth, many scholars have done a lot of research. However, The article is based on a new path by means of previous new growth theory - Romer knowledge spillover model to use empirical research methods to explore human capital contribution to the development of tertiary industry.

\section{LITERATURE REFERENCES}

In 1960s, "The father of the human capital" Schultz (T. W. Schultz) (1960) formally proposed the concept of human capital, and pointed out that unlike material capital, human capital mainly is characteristic of human knowledge, ability, skills etc; Like other capital, human capital will bring great contribution to economic development, while emphasizing the improvement of human capital factor will bring to economic growth, which is far more than the material capital contribution [1]. In this period, the theory of economic growth has entered a golden period, economists who taking Solow as the representative of the neoclassical economic growth theory economists continued to emerge. Arrow(1962)were not satisfied with the view which considered technical as an exogenous variable, proposing a "learning by doing" model, and the variable technical progress was internalized in model [2]; Uzawa (1965) divided the capital into two types of material capital and human capital, and it is the first time that the human capital has been introduced to the economic growth theory[3]. By the age of 1980 s, new economic growth theory which took the knowledge economy as the background was born, the human capital as a new factor of production was included in the economic growth model, and the study of human capital has thus entered a new stage. The most representative personages are Paul Romer and Robert Lucas. Romer (1986) inherited Arrow's research thought, having become the most important creator of a new economic growth theory. According 
to this, He proposed two endogenous growth models. His first model does not lead into the concept of "human capital", but he used the "knowledge" instead of "capital", and drew into Knowledge spillover effect, holding that the accumulation of knowledge is the source of economic growth[4]; In the second model, Romer (1990) formally introduced the concept of "human capital", dividing the output into two parts:Consumption and production department and R\&D department or knowledge accumulation department, but production input contains four aspects: material capital $(\mathrm{K})$, unskilled labor $(\mathrm{L})$, the level of human capital $(\mathrm{H})$ and the level of Technology (A), wherein, the level of human capital is the most important[5]. So human capital has become an independent impact factor of economic growth, and he thought that only human capital can promote economic growth. Lucas (1988) integrated the Arrow's views and Uzawa model, proposing Locust human capital accumulation and overflow model, and he combined Schultz's human capital with Solow's technology progress view, attributing to "specialized human capital " and used it as a real source of economic growth[6]. After that, Some western scholars study concluded that human capital investment is not only developed countries, but it is also the key for developing countries to achieve sustained economic growth.

For domestic research in this area is relatively large. Shengbin Yang, Juanjuan Chen(2013) by the Cobb Douglas production function, selected the 1996-2010 year data, verifying the positive contribution of human capital to the development of our country's third industry[7]. Jiansen Niu (2014)took 1991-2012 years of Tibet data for example, using C-D production function model, and the method of regression analysis, and concluded physical capital and human capital contribution to economic growth rate, finding that all two types of capital will have a great effect on economic development[7]. Yanxia Ge(2014) has analyzed the inter-provincial panel data by using the pulse effect of VAR model to verify that the change of human capital had an effect on total factor productivity, showing that the increase of human capital can significantly promote the improvement of TFP, and has great significance to the economic development[8]. Wei Du, Zhijiang Yang(2014) selected the panel data of Chinese provinces during 2002-2010, on the one hand, he had verified that the human capital had an effect on economic growth, and also studied regional differences that human capital played a role[9]. Zengming Jiang, Huili Ma(2014) estimated the level of human capital of our country's tertiary industry in 1996-2011, and built human capital measurement model, obtaining the human capital has become an important growth engine of development of China's third industry[10]. By using the extended Solow model and empirical analysis of the collected data, Dehuang Li, Enjun Xia(2013)obtained human capital and technological progress has become the main factors of economic development, but the influence of workforce decreased gradually[11]. Yuejun Jing, Xiaohong Liu(2013) verified the stock of human capital of China's contribution to economic growth, but also found the current situation that China's human capital accumulation is insufficient by using Lucas spillover model and selecting time series data[12]. As can be seen from the study of the above scholars, most of them focused on human capital effect on economic growth, and models are mostly used in the form of various modifications Cobb-Douglas production function and Lucas model, at the same time, in order to demonstrated human capital influence on economic development, the most scholars chose to use regression analysis method. But few scholars considered that the human capital level high or low, input more or less played the role of the third industry. Therefore, this paper will aim to conduct research from a new perspective to make up for lack of predecessors, causing the great attention of scholars for this study. That is, using the model of knowledge spillover of Romer as the theoretical basis discusses human capital investment of Shandong province contribution to the development of the third industry, and also provides a theoretical basis for the better development of the tertiary industry.

\section{Research Methods, Models And Data}

\section{A. Construction of the Model}

According to the theory of new economic growth model shows that the existence of knowledge spillover effect of human capital can not only save labor costs, improving labor productivity, but it also has become an "engine" driving economic development. From the current status of the development of the third industry in Shandong province being seen, only the development of Romer's knowledge spillover model can better describe the third industry in Shandong province. Thus, this paper adopts knowledge spillover model of Romer to explore human capital contribution to the development of the third industry.

The specific form of Romer's knowledge spillover model is:

$$
Y=A \bullet K^{\alpha} \bullet L^{\beta} \bullet H^{\gamma}
$$

Thereinto, Y represents the output; $\mathrm{K}$ stands for capital investment; $L$ represents effective labor input; A represents the technology progress; $H$ indicates the level of human capital; $\alpha$, $\beta, \gamma$ represent respectively output elasticity coefficient of the fixed capital, effective labor input and human capital.

In order to facilitate the calculation and application of linear regression, the two sides of the equation have logarithmic type:

$$
L n Y=L n A+\alpha \operatorname{LnK}+\beta \operatorname{Ln} L+\gamma L n H
$$

In order to eliminate the collinearity problem, (2) type is transformed to dimensionality reduction, and gets the following equation:

$$
L n Y-L n L=L n A+\alpha \times(L n K-L n L)+\gamma \times L n H
$$

According to (3)type collating relevant data, this paper accordingly conducts linear regression, seeking value $\alpha, \beta, \gamma$, and further calculates each factor of production contribution to the development of tertiary industry.

\section{B. Selection of Variables and Data Sources}

In this paper, the required data mainly comes from the "Shandong statistical yearbook 2013" and 2010 census statistics. This paper selects time series data of 1997-2012 years in Shandong province, wherein, $\mathrm{Y}$ is represented with the GDP of tertiary industry; $\mathrm{K}$ is represented with fixed asset investment; For selecting the level of human capital $\mathrm{H}$, there 
are many methods, such as average years of schooling, the income approach, the investment cost method and so on, but considering availability and easy operation of the data, this paper selects average years of schooling to calculate the level of human capital; Effective labor input L is calculated as follows: $\mathrm{L}=$ average education level*the labor force of the third industry.

\section{Research Methods and Data Processing}

In this paper, using the data in Table 1 and the formula (3), takes the natural logarithm and standardization of data, and linear regression was performed by using STATA12. 0 statistical analysis software. The results obtained are shown in table 2:

\begin{tabular}{|} 
TABLE II \\
\begin{tabular}{|c|c|c|c|c|c|c|}
\hline $\mathbf{y}$ & Coef. & $\begin{array}{c}\text { Std. } \\
\text { Err. }\end{array}$ & $\mathbf{t}$ & $\mathbf{P}>|\mathbf{t}|$ & \multicolumn{2}{|c|}{$\begin{array}{c}\text { [95\% Conf. } \\
\text { Interval] }\end{array}$} \\
\hline LnK-LnL & 0.6856 & $\begin{array}{c}0 . \\
0229\end{array}$ & 29.95 & $\begin{array}{c}0 . \\
000\end{array}$ & $\begin{array}{c}0 . \\
63571\end{array}$ & $\begin{array}{c}0 . \\
7355\end{array}$ \\
\hline dLnH & 1.3727 & $\begin{array}{c}0 . \\
4879\end{array}$ & 1.09 & $\begin{array}{c}0 . \\
016\end{array}$ & 0.3097 & $\begin{array}{c}2 . \\
4357\end{array}$ \\
\hline _cons & 0.1348 & $\begin{array}{c}0 . \\
0.15\end{array}$ & 4.28 & $\begin{array}{c}0 . \\
001\end{array}$ & $\begin{array}{c}0 . \\
06616\end{array}$ & $\begin{array}{c}0 . \\
2035\end{array}$ \\
\hline F( 2, 12) & 463.22 & \multicolumn{2}{|c|}{ Prob $>\mathbf{F}$} & \multicolumn{2}{c|}{0.0000} \\
\hline R-squared & \multicolumn{2}{|c|}{0.9872} & $\begin{array}{c}\text { Adj R- } \\
\text { squared }\end{array}$ & \multicolumn{2}{|c|}{0.9851} \\
\hline
\end{tabular}
\end{tabular}

As can be seen from table 2, the correlation coefficient R2 between human capital investment and the development of the third industry is 0. 9871; Adj R-squared is 0. 9851; The significant value (Prob $>$ F) is 0 . 000; The F value is 463. 22 . Above these can indicate that the correlations between variables regression is very good; Fitting degree is very high, and independent variables have a significantly effect on the dependent variable. Furthermore, significant values of variables are $0.000,00016$ and 0.001 , respectively, and they are smaller than the significance level of 0.05 ; $T$ values are 29.95, 1. 09, 4. 28 , respectively, and the absolute values are relatively large, indicating that independent variables have great influence on the dependent variable. From the view of elastic coefficient, output elasticity coefficient $\alpha$ of fixed capital is 0.686 ; Output elasticity coefficient $\beta$ of effective labor is 0 . 314; Output elasticity coefficient $\gamma$ of human capital level is 1.373 . These coefficients are positive, which demonstrates that each factor of production has positive impacts on outputs. Therefrom, Thus, this paper gets knowledge spillover model of Romer is as follows:

$$
Y=A \bullet K^{0.686} \bullet L^{0.314} \bullet H^{1.373}
$$

As can be seen from the model, each unit of effective labor input can lead to the output growth of 0.314 percentage point; each unit of human capital level can bring the output growth 1 . 373times.

Utilizing the above information and selecting data from 1997 to 2012, this paper further calculates the contribution rate of productive factors to value-added of the third industry in Shandong Province in each period. Specific data is shown in the table 3:

From table 3, the following conclusions can be drawn:
Firstly, the level of human capital plays a very important role in promoting the growth of the third industry added value, and since 1997, the level of human capital is growing in each period, its growth rate being $1.01 \%$; At the same time, the contribution which is the third industry added value brought by the human capital level is growing, its contribution rate being $77.47 \%$.

Furthermore, compared with the fixed capital investment, human capital investment is still a big gap, causing the contribution which human capital brings also has the very big disparity with the fixed capital. Obviously, it also shows that the current development of tertiary industry in Shandong Province mainly relies on traditional service industry of fixed capital investment, and the development level of the third industry is still relatively low.

\section{SUGGestions}

The third industry to develop, the talents must go ahead of the rest. As also can be seen from the above analysis, Human capital investment has significantly contributed to the development of the third industry, but there exists fairly big disparity compared with the fixed capital investment. Therefore, the paper may believe that we should take some feasible measures to increase human capital investment, in order to better promote the development of the third industry in Shandong province.

On the one hand, we should change the traditional values of "pure capital view", and enhance the awareness that human capital is considered as the first capital. The 21 st century is the era of knowledge economy, in this new era, and each company is increasingly aware of that the key which improves the overall competitiveness of firms is the competition of talents. It is of source of sustained and healthy development of enterprises to establish the correct concept of human capital investment, and constantly strengthen human capital investment of companies, because human capital investment can bring many benefits including investment height increment, the income diversity, the long-term benefits and so on. The practice research of domestic and international economic development has also proved that lacking of necessary human capital investment, even if all the elements are available, they also cannot achieve good economic benefit or are impossible to obtain better economic benefits in the long term. Therefore, in the process of economic development, we must adhere to the people-oriented concept, and consider firstly human capital as the first factor.

On the other hand, it is necessary for the government to reform the single educational investment system, adjust the structure of education, and implement the teaching and educational mode which is the organic integration of production, education and research. Nowadays, with the development of society and economy, especially the development of the third industry, is more dependent on human capital investment compared to the past physical capital investment, but the cultivation of talents and improvement of talents quality are more dependent on education. Education is the foundation of building a country and talents are the key to the strength of a country, so investment in education is to invest in the future. Currently, the biggest problem which the 
education faces is a serious investment system simplification. Therefore, to solve this problem, the educational investment system which is the whole society and the pattern of omnidirectional should be established, increasing constantly investment in education funding. While it is the government that continue to improve the structure of education and strengthen matching degree of the proportion of industry, learning and research, matching, evolving a multileveled educational pattern and constructing lifelong educational system, they should also try their best to train and bring up a batch of high-quality services personnel so that these speed up the development of the third industry in Shandong province.

Moreover, it is of importance for the companies to establish a scientific employment mechanism and attracting and encouraging mechanism for the talented, knowing the person friendly to use. Reasonable employment mechanism can effectively exploit potentialities employment mechanism of talents, and let the right people work most effectively in the appropriate position, so that the firms can "give full scope to the talents and make the best use of everything"and maximize improve labor efficiency. For the absorption of talents, on the one hand, you should focus on training local talent, but also pay more attention to the absorption and the introduction of external talent. Especially the development of the third industry is the need for more highly skilled, high-quality, and comprehensive talents so that these can allow enterprises to" infuse fresh blood". Besides, "Knowing people"is the premise of "proper selection of personnel", and after "Knowing people", firms should use one's strengths, weaknesses of those who are never used. Fully grasping the talents, the enterprises should not only focus on education, but breed misconceptions which ignore the ability of talents, so that they can better retain talents, making contributions to promote the development of tertiary industry in Shandong province.

\section{ACKNOWLEDGMENT}

Funded Project:The Paper is the key project of social science planning research projects in Shandong province: Talent issues research of the development of characteristic industry town in Shandong province ( 12BGLJ03) \The research results are funded by the base of scientific research innovation of the regional innovation and sustainable development in Shandong province.

\section{REFERENCES}

[1] Schultz T W. (1961). Investment in Human Capital. [J]. American Economic Review. 51(1961).

[2] Arrow, K. J. (1962). The Economic Implications of Learning by Doing, Review of Economic Studies. 80. 29 (1962), pp. 155-73.

[3] Uzawa, H. (1965). Optimal Technical Change in an Aggregative Model of Economic Growth. International Economic Review. 6 (1965), pp. 1831.

[4] Romer, P. M. (1986). Increasing Returns and Long Run Growth. Journal of Political Economy. 5. 94(1986), pp. 1002-37.

[5] Romer. P. M. Endogenous Technological Change. [J]. Journal of Political Economy. 5. 98 (1990), pp. 71 - 102.

[6] Lucas, R. E, Jr. (1988). On the Mechanics of Economic Developm- ent. [J]. Journal of Monetary Economics. 22(1988), pp. 783-792.

[7] Shengbin Yang, Juanjuan Chen. Research on Human Capital Contribution to the Development of Tertiary Industry in Our Country. [J]. China Venture Capital. 4(2013), pp. 28.

[8] Jianshen Niu. An Empirical Analysis on Human Capital Investment Contribution to Economic Growth in Tibet. [J]. Times Finance. 4 (2014), pp. 67.

[9] Yanxia Ge. Long-term Dynamics Effects of Human Capital on Total Factor Productivity-Impulse Response Analysis Based on VAR Model [J]. Future and Development. 9(2014), pp. 58.

[10] Wei Du, Zhijiang Yang. The Mechanism of Action Research on Human Capital Promoting Economic Growth. [J]. China Soft Science. 8(2014), pp. 173.

[11] Zengming Jiang, Huili Ma. Analysis of human capital measurement and contribution rate. [J]. Commercial Times. 3 (2014), pp. 109.

[12] Dehuang Li, Enjun Xia. The Impact of Human Capital on Economic Growth in China-Based on Extensive Solow Model. [J]. China Population Resources and Environment. 8(2013), pp. 100.

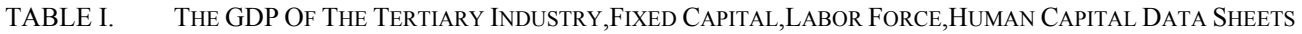

\begin{tabular}{|c|c|c|c|c|c}
\hline Year & $\begin{array}{c}\text { GDP } \\
(\mathbf{Y})\end{array}$ & $\begin{array}{c}\text { Fixed Asset } \\
\text { Investment } \\
(\mathbf{K})\end{array}$ & $\begin{array}{c}\text { The Level of } \\
\text { Force(l) }\end{array}$ & $\begin{array}{c}\text { Human } \\
\text { Capital } \\
(\mathbf{H})\end{array}$ & $\begin{array}{c}\text { Effective } \\
\text { Labor } \\
\text { Input (L) }\end{array}$ \\
\hline 1997 & 2194.70 & 768.38 & 1131.6 & 6.50 & 7358.95 \\
\hline 1998 & 2397.49 & 972.72 & 1204.5 & 6.62 & 7973.26 \\
\hline 1999 & 2628.52 & 1157.7 & 1257.3 & 6.82 & 8580.66 \\
\hline 2000 & 2904.45 & 1288.8 & 1268.1 & 7.12 & 9027.10 \\
\hline 2001 & 3279.53 & 1423.1 & 1303.1 & 7.58 & 9881.50 \\
\hline 2002 & 3700.52 & 1727.0 & 1382.3 & 8.08 & 11168.28 \\
\hline 2003 & 4112.43 & 2361.5 & 1508.0 & 7.85 & 11840.51 \\
\hline 2004 & 4764.70 & 2802.3 & 1605.0 & 7.94 & 12749.94 \\
\hline
\end{tabular}

\begin{tabular}{c|c|c|c|c|c|}
\hline Year & GDP (Y) & $\begin{array}{c}\text { Fixed Asset } \\
\text { Investment } \\
(\mathbf{K})\end{array}$ & $\begin{array}{c}\text { Labor } \\
\text { Force(l) }\end{array}$ & $\begin{array}{c}\text { The Level } \\
\text { of Human } \\
\text { Capital } \\
(\mathbf{H})\end{array}$ & $\begin{array}{c}\text { Effective } \\
\text { Labor } \\
\text { Input (L) }\end{array}$ \\
\hline 2005 & 5924.74 & 3579.6 & 1709.0 & 7.72 & 13196.65 \\
\hline 2006 & 7187.26 & 3935.6 & 1761.7 & 8.09 & 14258.62 \\
\hline 2007 & 8620.24 & 4668.4 & 1826.3 & 8.23 & 15022.25 \\
\hline 2008 & 10358.64 & 6690.6 & 1918.6 & 8.28 & 15876.53 \\
\hline 2009 & 11768.18 & 8800.8 & 1982.7 & 8.31 & 16481.74 \\
\hline 2010 & 14343.14 & 11392.5 & 2042.1 & 8.17 & 16688.03 \\
\hline 2011 & 17370.89 & 12968.5 & 2088.4 & 8.67 & 18112.06 \\
\hline 2012 & 19995.81 & 15207.9 & 2141.1 & 8.78 & 18797.72 \\
\hline
\end{tabular}

TABle III. The CONTribution Rate Of Productilve Factors To VAlue-AdDed Of The Third Industry EACH PERIOD

\begin{tabular}{|c|c|c|c|c|c|c|c|}
\hline \multirow{2}{*}{ Period } & \multirow{2}{*}{$\begin{array}{c}\text { Value-added of } \\
\text { Tertiary } \\
\text { Industry } \\
\text { Growth Rate } \\
\mathbf{( \% )}\end{array}$} & \multicolumn{2}{|c|}{$\begin{array}{c}\text { Production Factors Input Growth } \\
\text { Rate (\%) }\end{array}$} & \multicolumn{2}{|c|}{$\begin{array}{c}\text { The Contribution of Production } \\
\text { Factors (\%) }\end{array}$} \\
\cline { 3 - 8 } & Fapital & $\begin{array}{c}\text { Effective } \\
\text { Labor }\end{array}$ & $\begin{array}{c}\text { Human } \\
\text { Capital }\end{array}$ & $\begin{array}{c}\text { Fixed } \\
\text { Capital }\end{array}$ & $\begin{array}{c}\text { Effective } \\
\text { Labor }\end{array}$ & $\begin{array}{c}\text { Human } \\
\text { Capital }\end{array}$ \\
\hline $2002-2007$ & 1.7 & 2.24 & 0.644 & 0.159 & 90.39 & 11.895 & 12.84 \\
\hline $2008-2012$ & 1.41 & 1.86 & 0.352 & 0.569 & 90.49 & 7.84 & 55.41 \\
\hline $1997-2012$ & 1.79 & 20.81 & 0.66 & 1.01 & 107.69 & 11.58 & 77.47 \\
\hline
\end{tabular}


